\title{
AMAR
}

AMAR (Andalas Management Review)

Vol. 4, No. 1 (2020) 56-81

The Management Institute, Faculty of Economics, Universitas Andalas

ISSN (Print) 2476-9282 | ISSN (Online) 2548-155X

\section{Analisis Faktor-Faktor yang Mempengaruhi Intensi Adopsi Teknologi Informasi pada Industri Kreatif di Sumatera Barat}

\author{
Danny Hidayata, Harif Amali Rivai ${ }^{\mathrm{b}}$ \\ a,bDepartment of Management Faculty of Economics Universitas Andalas, dannyhidayat@eb.unand.ac.id
}

\begin{abstract}
This research was conducted to determine the factors that influence the intention of adopting information technology in the creative industry in West Sumatra. This research was conducted in West Sumatra with the object of small and medium enterprises based on creative industries in West Sumatra. The population in this study were all owners or managers of small and medium enterprises based on creative industries in West Sumatra. The population size is unknown. The sampling method was purposive sampling with a sample of 200 people. The data analysis technique used SEM (structural equation modeling) which is operated through the SMART / PLS program. The results of this study indicate that the information quality variable has a negative and insignificant effect on perceptions of benefit, the self-efficacy variable has a positive and insignificant effect on perceptions of usefulness, government support has a positive and insignificant effect on perceptions of benefit, and system quality variables have a positive and significant effect on perceptions. On the benefit and the perception variable on the benefit has a positive and significant effect on the interest in using it.

Keywords: information quality, self-efficacy, government support, system quality, interest
\end{abstract}

\section{PENDAHULUAN}

Saat ini telah banyak para khalayak umum yang mencoba menjajal usahanya di bidang industri kreatif, walaupun masih samar-samar akan tetapi usaha di bidang industri kreatif ini sangatlah menjanjikan keuntungan, terutama di zaman perkembangan teknologi saat ini yang menuntut kita untuk lebih kreatif lagi. Apalagi saat ini sudah banyak teknologi -teknologi yang menunjang masyarakat untuk lebih mengasah kreatifitasnya, industri kreatif saat ini sedang marak di sebagian besar belahan dunia banyak perusahaan-perusahaan yang mulai menekuni usaha ini karena hasilnya yang menguntungkan terlebih lagi berkembangnya teknologi yang setiap tahun semakin maju.

Di Indonesia sendiri industri kreatif telah bergulir beberapa tahun, , Ekonomi kreatif dan Industri Kreatif semakin hangat dibicarakan baik oleh pemerintah, swasta dan pelakunya sendiri. Khususnya pemerintah yang sudah semakin menaruh perhatiannya. Sedikitnya ada Departemen Perdagangan, Departemen Perindustrian, Departemen Komunikasi dan Informatika, dan Departemen Tenaga Kerja. Kementrian Perdagangan Republik Indonesia mendefinisikan Industri kreatif sebagai Industri yang berasal dari pemanfaatan kreativitas, keterampilan serta bakat individu untuk menciptakan kesejahteraan serta lapangan pekerjaan melalui penciptaan dan 
pemanfaatan daya kreasi dan daya cipta individu tersebut. Industri kreatif berbasis pada sumber daya yang terbarukan, menciptakan inovasi dan kreativitas yang merupakan keunggulan kompetitif suatu bangsa serta memberikan dampak sosial yang positif. . John Howkins dalam The Creative Economy (2001) menemukan kehadiran gelombang ke-empat yang berbasis pada kreatifitas dan inovasi. Dia mengusulkan 15 kategori industri yang termasuk dalam ekonomi kreatif, yaitu yaitu periklanan, arsitektur, seni rupa, kuliner, kerajinan atau kriya, desain, fesyen, video, permainan interaktif, musik, seni pertunjukan, penerbitan dan percetakan, layanan computer dan piranti lunak, TV dan Radio, riset dan pengembangan, kuliner. Dari semua kategori tersebut semuanya ada di Indonesia.

Sumatra Barat sebagai salah satu provinsi di Indonesia memiliki potensi pasar industri kreatif ini dapat dilihat dari hampir setiap kabupaten/kota memiliki produk kreatif baik berupa produk makanan atau kuliner, seni, ukiran, hingga pakaian yang perlu pengembangan yang lebih luas. Hal ini setidaknya memberikan gambaran terhadap potensi dan keberadaan industri kreatif yang ada di Sumatra Barat. Potensi industri kreatif ini, diharapkan bisa memberikan kontribusi terhadap pertumbuhan nasional. Untuk mendukung potensi pasar dalam industri ini, para pemain harus mampu bersaing. Salah satu upaya yang bisa dilakukan adalah dengan mengadopsi teknologi informasi. Perkembangan teknologi informasi mampu menciptakan pola kerja, pola produksi dan pola distribusi yang efektif dan efisien, sehingga kegiatan produktivitas menjadi lebih produktif.

Sehubungan dengan perilaku seseorang untuk dapat menerima atau menolak penggunaan Teknologi Informasi, maka terdapat sebuah model yang dikembangkan dengan nama Technology Acceptance Model (TAM). TAM dapat diartikan sebagai sebuah model penelitian yang menjelaskan perilaku adopsi sistem informasi atau teknologi informasi (Chau, 1996, dalam Sanjaya, 2005). TAM merupakan adaptasi dari Theory of Reasoned Action Model (TRA) yang dikembangkan oleh Fishbein dan Ajzen (1975) dalam Sanjaya (2005). TAM merupakan salah satu model baku (established) karena telah diuji secara empiris. TAM dibuat khusus untuk pemodelan adopsi pengguna sistem informasi. Menurut Davis (1989), tujuan utama TAM adalah untuk mendirikan dasar penelusuran pengaruh faktor eksternal terhadap kepercayaan, sikap (personalisasi), dan tujuan pengguna komputer. TAM menganggap bahwa dua keyakinan variabel perilaku utama dalam mengadopsi sisitem informasi, yaitu persepsi pengguna terhadap manfaat (perceived of usefulness) dan persepsi pengguna terhadap penggunaan (perceived ease of use). Perceived of usefulness diartikan sebagai tingkat dimana seseorang percaya bahwa menggunakan sistem tertentu dapat meningkatkan kinerjanya, dan perceived ease of use diartikan sebagai tingkat dimana seseorang percaya bahwa menggunakan sistem tidak diperlukan usaha apapun (free of effort). Perceived ease of use juga berpengaruh pada perceived usefulness yang dapat diartikan bahwa jika seseorang merasa sistem tersebut mudah digunakan maka sistem tersebut berguna bagi mereka. 
Selain menggunakan variabel-variabel TAM, penelitian ini juga menggunakan variabel Kualitas informasi, self efficacy, kualitas sistem, dan dukungan pemerintah yang juga merupakan faktor-faktor penting yang mempengaruhi penggunaan teknologi. Kualitas informasi merupakan salah satu faktor yang mempengaruhi minat seseorang menggunakan IT hal tersebut diperkuat oleh penelitian yang dilakukan oleh Ahn et al.(2007)yang menejelaskan bahwa kualitas informasi berpengaruh terhadap persepsi atas kemanfaatan. Bandura (1977) mendefinisikan efficacy sebagai keyakinan seseorang bahwa dirinya dapat melakukan sebuah pekerjaan dengan baik. Penelitian yang dilakukan oleh Singh dan Punia (2010) membuktikan bahwa keberhasilan diri atas penggunaan teknologi informasi berpengaruh positif terhadap minat perilaku penggunaan teknologi informasi.

Selain dari kualitas sistem dan dan efikasi diri Dukungan pemerintah juga merupakan variabel yang penting dalam mempengaruhi penggunaan teknologi. Ketiadaan dukungan organisasi dianggap sebagai penghalang utama keberhasilan pemanfaatan suatu sistem (Igbaria, 1990, mengutip dari Chatzoglou, et al., 2010; Igbaria, et al., 1997; Kim, et al., 2007). Disamping itu kualitas sistem juga merupakan faktor penting dalam kepuasan pengguna IT dalam menggunakan sistem yang menjadi ukuran adalah penampilan, kecepatan, keamanan dan privasi. liao dan Chaung (2001) menunjukkan bahwa kualitas sistem memiliki dampak positif pada persepsi kemudahan penggunaan dan kegunaan dari situs.

Dari uraian di atas penulis tertarik untuk mengangkat tema ini sebagai objek penelitian dengan judul: “Analisis Faktor Faktor yang Mempengaruhi Intensi Adopsi Teknologi Informasi pada Industri Kreatif di Sumatera Barat."

\subsection{Rumusan Masalah}

Berdasarkan latar belakang masalah yang telah diuraikan di atas, dapat dirumuskan permasalahan penelitian sebagai berikut:

a. Bagaimana pengaruh kualitas informasi terhadap persepsi pengguna manfaat teknologi informasi?

b. Bagaimana pengaruh efikasi diri terhadap persepsi pengguna manfaat teknologi informasi?

c. Bagaimana pengaruh dukungan pemerintah terhadap persepsi pengguna manfaat teknologi informasi?

d. Bagaimana pengaruh kualitas sistem terhadap persepsi pengguna manfaat teknologi informasi?

e. Bagaimana pengaruh persepsi pengguna manfaat teknologi informasi terhadap minat menggunakan teknologi informasi?

\subsection{Ruang Lingkup Penelitian}


Dalam melakukan penelitian, penulis membatasi ruang lingkup penelitian, dimana penulis melakukan penelitian pada pemilik atau pengelola UKM di Provinsi Sumatera Barat. Ruang lingkup yang di teliti adalah kualitas informasi, efikasi diri, dukungan pemerintah, kualitas sistem, persepsi pengguna manfaat teknologi informasi dan minat menggunakan teknologi informasi. Penyebaran kuesioner dilakukan pada 200 pemilik atau pengelola UKM di Provinsi Sumatera Barat.

\subsection{Tinjauan Literatur}

\section{a. Minat Menggunakan Teknologi Informasi}

Adopsi teknologi sebagai hasil atas penerimaan teknologi oleh pemakai akhir didasarkan pada persepsi kemanfaatan serta kemudahan dalam penggunaan teknologi tersebut menghasilkan perilaku dan perhatian untuk menggunakan teknologi baru (Bahmanziari et.al., 2003). Persepsi kemanfaatan dapat didefinisikan sebagai tingkat dimana individu percaya bahwa menggunakan sebuah bagian sistem dapat meningkatkan performa kerjanya, sedangkan persepsi kemudahan merupakan tingkat dimana seorang individu yang menggunakan sebuah bagian sistem akan lebih meringankan beban fisik maupun mental penggunanya (Moore, G.C \& Benbasat, I, 1991; Davis, 1986). Keputusan untuk mengadopsi teknologi ini dapat pula dihubungkan dengan bagaimana pengembangan inovasi dalam teknologi informasi tersebut.

Menurut Davis (1989) Intensi untuk mengadopsi adalah kecenderungan perilaku untuk tetap menggunakan suatu teknologi. Hermawan (2008) mendefinisikan minat perilaku menggunakan teknologi (intention to use) sebagai minat atau keinginan seseorang untuk melakukan perilaku tertentu. Triandis (1980) mengemukakan bahwa perilaku seseorang merupakan ekspresi dari keinginan atau minat seseorang (intention), dimana keinginan tersebut dipengaruhi oleh faktor - faktor sosial, perasaan (affect), dan konsekuensi - konsekuensi yang dirasakan. Davis et.al. (1989) mengemukakan bahwa adanya manfaat yang dirasakan oleh pemakai teknologi informasi akan meningkatkan minat mereka untuk menggunakan teknologi informasi. Sedangkan Thompson et.al., (1991) menyatakan bahwa keyakinan seseorang akan kegunaan teknologi informasi akan meningkatkan minat mereka dan pada akhirnya individu tersebut akan menggunakan teknologi informasi dalam pekerjaannya.

\section{b. Persepsi Kualitas Informasi Terhadap Teknologi}

Dalam penggunaan sisitem informasi,informasi itu sendiri sangatlah penting karena dengan adanya informasi itu individu akan merasa yakin dalam melakukan pekerjaannya dan akan mendapatkan hasil yang maksimal. Informasi adalah hal yang diperlukan bagi pemakai teknologi informasi yang baru untuk dapat meningkatkan kinerja dalam menjalankan kegiatan operasional. 
Menurut Jogiyanto (2007) mengemukakan bahwa Kualitas informasi mengukur kualitas keluaran dari sistem informasi. Ong et al. (2009) berpendapat bahwa Kualitas informasi dapat diartikan pengukuran kualitas konten dari sistem informasi. Negash et al. (2003) menjelaskan Kualitas informasi adalah suatu fungsi yang menyangkut nilai dari keluaran informasi yang dihasilkan oleh sistem. Berdasarkan beberapa pendapat para ahli, dapat disimpulkan bahwa kualitas informasi adalah suatu pengukuran yang berfokus pada keluaran yang diproduksi oleh sistem, serta nilai dari keluaran bagi pengguna. Jogiyanto (2005) menjelaskan bahwa kualitas informasi terdiri tiga hal yaitu Akurat, tepat pada waktunya, dan relevan. Dalam penelitian lain Ahn et al. (2007)menejelaskan bahwa kualitas informasi berpengaruh terhadap persepsi atas kemanfaatan

\section{c. Self-efficacy}

Menurut pervin dan john (1997)self efficacy adalah suatu kemampuan yang dimiliki oleh individu untuk membentuk prilaku yang relevan pada tugas atau situasi khusus. Pengertian self-efficacy menurut Bandura (1997) adalah penilaian seseorang terhadap kemampuannya diri yang disesuaikan dengan hasil yang dicapai. Self-efficacy terkait dengan pertimbangan tentang apa yang bisa dilakukan terkait dengan keterampilan yang dimilikinya. Sumber utama dari self-efficacy adalah persepsi dan interpretasi secara fisik dan emosi.

Menurut Davis (1989) perceived ease merupakan variabel perluasan dari self efficacy yang diteorikan sebagai determinan dari perilaku. Seseorang akan mempertimbangkan keyakinannya dalam melakukan tindakan didasarkan atas emosi yang pernah dilalui sebagai dasar dalam menyelesaikan tindakan. Self- efficacy berperan dalam mempengaruhi proses motivasi melalui sejumlah usaha yang akan digunakan individu dan seberapa lama mereka terus bekerja pada tugasnya saat ada hambatan. Individu dengan self-efficacy rendah akan merusak motivasi melalui perasaan bahwa mereka tidak mampu untuk menyelesaikan tugas itu, sebelum tugas tersebut dicobanya. Pengaruh self-efficacy pada proses affective bisa dilihat pada tingkat stress dan depresi dari pengalaman individu pada situasi yang susah dan mengancam (Bandura, 1997).

Davis et al. (1989) memformulasikan model TAM, dan memberikan saran bahwa penelitian dimasa yang akan datang perlu melakukan pengujian variabel eksternal dalam memahami bagaimana seseorang bisa menerima atau menolak sistem teknologi informasi. Dari beberapa hasil penelitian empiris yang telah dilakukan, diperoleh hasil bahwa faktor selfefficacy masuk pada lingkungan teknologi komputer, faktor tersebut berhubungan secara signifikan dengan persepsi para pemakai tentang teknologi tersebut (Burckhardt and Brass 1990; Gist et al. 1989; Hill et al. 1987 dalam Schillewaert, et al., 2000).

\section{d. Persepsi Atas Kemanfaatan}


Persepsi Manfaat adalah suatu tingkatan dimana seseorang percaya bahwa penggunaan suatu teknologi tertentu akan meningkatkan prestasi kerja orang tersebut. Sesuai dengan TAM, penggunaan sistem dipengaruhi oleh minat untuk menggunakan. Pengukuran kemanfaatan tersebut berdasarkan frekuensi penggunaan dan diversitas aplikasi yang dijalankan. Menurut Davis (1989), persepsi kegunaan (perceived usefulness) didefinisikan sebagai sejauh mana seseorang percaya bahwa dalam menggunakan teknologi tertentu akan dapat meningkatkan kinerjanya. Jadi, orang-orang cenderung akan menggunakan atau tidak menggunakan suatu aplikasi sejauh bahwa mereka percaya hal itu akan meningkatkan kinerja dari pekerjaan mereka. Menurut Philips et al (1994) dalam (Teo, Lee, dan Chai, 2007), persepsi kegunaan (perceived usefulness) mencerminkan probabilitas subjektif dari calon pengguna yang menerapkan teknologi baru, apakah akan bermanfaat bagi diri sendiri atau organisasinya. Konsep ini menggambarkan manfaat sistem bagi pemakainya yang berkaitan dengan produktivitas, kinerja tugas, efektivitas, pentingnya suatu tugas dan overall usefulness (Handayani, 2007). Oleh karena itu, menurut Koufaris (2002) persepsi kemudahan terdiri dari empat indikator, yaitu: mengembangkan kinerja (improve performance); meningkatkan produktivitas (increase productivity); meningkatkan efektivitas (increase effectiveness); serta bermanfaat (usefull).

Dengan definisi dan indikator-indikator yang telah disebutkan sebelumnya, dapat diartikan bahwa kebermanfaatan dari penggunaan teknologi informasi dapat meningkatkan kinerja dan prestasi orang yang menggunakannya. Kebermanfaatan dalam teknologi informasi merupakan manfaat yang diperoleh atau diharapkan oleh para pengguna dalam melaksanakan tugas dan pekerjaannya. Oleh karena itu, tingkat kebermanfaatan teknologi informasi mempengaruhi sikap para pengguna dalam mengadopsi teknologi tersebut. Persepsi kebermanfaatan (perceived usefulness) merupakan sesuatu yang menyatakan individu percaya bahwa penggunaan suatu teknologi tertentu akan meningkatkan kinerja dari individu. Wibowo (2008) menjelaskan bahwa persepsi kebermanfaatan merupakan suatu ukuran dimana penggunaan suatu teknologi dipercaya akan mendatangkan manfaat bagi orang yang menggunakannya. Sikap seseorang dalam menggunakan teknologi informasi diprediksikan, jika seseorang tersebut mempercayai bahwa teknologi informasi dapat memberikan manfaat terhadap pekerjaannya dan pencapaian prestasi kerjanya. Oleh karena itu, tingkat kemanfaatan teknologi informasi mempengaruhi sikap pengguna dalam menggunakan teknologi informasi tersebut.

\section{e. Persepsi Kualitas Sistem Terhadap Teknologi}

Sistem adalah suatu entity yang terdiri dari dua atau lebih komponen yang saling berinteraksi untuk mencapai tujuan. Sistem dilihat sebagai suatu komponen yang 
menyeluruh bukan pada subsistem atau satu subsistem, dengan berintegrasinya subsistem akan mengefisiensikan proses dengan mengurangi pengulangan (duplikat) data yang tidak perlu, penyimpanan, pelaporan dan proses-proses lainnya. Elemen-elemen sebuah sistem menurut hall (2001) mengemukakan sebuah sistem adalah sekelompok atau lebih komponen-komponen yang saling berkaitan atau subsistem-subsistem yang bersatu untuk mencapai tujuan yang sama.

Kualitas sistem dapat diartikan bahwa karakteristik kualitas yang diinginkan pengguna dari sistem itu sendiri. Asusmsi dasar model multi dimensional kesuksesan sistem informasi dapat dijelaskan dalam tiga level yang berbeda yaitu tingkat teknikal, semantik, dan keefektifan sistem. Tingkat teknikal dari komunikasi sebagai keakuratan dan keefisienan sistem komunikasi yang menghasilkan suatu informasi tingkat semantik merupakan kesuksesan informasi dalam menyampaikan maksud atau arti yang diharapkan. Indikator kualitas sistem diwujudkan dalam seperangkat pertanyaan kualitas sistem yang dapat diukur melalui beberapa indikator yaitu penampilan, kecepatan, keamanan, dan privasi.

\section{f. Dukungan Organisasi ( Pemerintah )}

Ada banyak studi dalam literatur sistem informasi yang sudah memperluas model TAM dengan menambahkan variabel eksternal mengenai fitur teknologi, situasi riset dan tujuan (Kim, et al., 2007). Ketiadaan dukungan organisasi dianggap sebagai penghalang utama keberhasilan pemanfaatan suatu sistem (Igbaria, 1990, mengutip dari Chatzoglou, et al., 2010; Igbaria, et al., 1997; Kim, et al., 2007).

Usaha Kecil dan Mikro (UKM) merupakan sektor yang penting dan besar kontribusinya dalam mewujudkan sasaran-sasaran pembangunan ekonomi nasional, seperti pertumbuhan ekonomi, kesempatan kerja, peningkatan devisa negara, dan pembangunan ekonomi daerah. UKM diharapkan mempunyai kemampuan untuk ikut memacu pertumbuhan ekonomi nasional sehingga UKM membutuhkan pelindung berupa kebijakan pemerintah seperti undang-undang dan peraturan pemerintah. Adanya regulasi baik berupa undangundang dan peraturan pemerintah yang berkaitan dengan UKM dari sisi produksi dan sisi perbankan, akan memacu peranan UKM dalam perekonomian. Seperti yang diungkapkan oleh George. J. StiglerdalamMandala Harefa (2008)Regulasi adalah seperangkat aturan yang dimaksudkan untuk memberikan perlindungan dan manfaat untuk masyarakat pada umumnya atau pada sekelompok masyarakat".

\subsection{Tinjauan Penelitian Terdahulu dan Hipotesis}

\section{a. Pengaruh Kualitas Informasi Terhadap Persepsi atas kemanfaatan}

Menurut Jogiyanto (2007) Kualitas informasi mengukur kualitas keluaran dari sistem informasi. Ong et al. (2009) berpendapat bahwa kualitas informasi dapat diartikan 
pengukuran kualitas konten dari sistem informasi. Negash et al. (2003) menjelaskan Kualitas informasi adalah suatu fungsi yang menyangkut nilai dari keluaran informasi yang dihasilkan oleh sistem.

Berdasarkan beberapa pendapat para ahli, dapat disimpulkan bahwa kualitas informasi adalah suatu pengukuran yang berfokus pada keluaran yang diproduksi oleh sistem, serta nilai dari keluaran bagi pengguna. Jogiyanto (2005) menjelaskan bahwa kualitas informasi terdiri tiga hal yaitu Akurat, tepat pada waktunya, dan relevan. Dalam penelitian lain Ahn et al. (2007) menejelaskan bahwa kualitas informasi berpengaruh terhadap persepsi atas kemanfaatan dalam menggunakan tekonologi. Oleh karena itu dirumuskan hipotesis pertama sebagai berikut: H1: Kepercayaan terhadap teknologi berpengaruh positif terhadap persepsi atas kemanfaatanTeknologi Informasi.

\section{b. Pengaruh self-efficacy terhadap persepsi kemanfaatan}

Pengertian self-efficacy menurut Bandura (1982) adalah penilaian seseorang terhadap kemampuan dirinya dalam mengorganisasi dan memutuskan tindakan yang diperlukan untuk mencapai kinerja yang diinginkan. Bandura (1982) menyatakan bahwa penelitianpenelitian mengenai self efficacy menghasilan sebuah perspektif yang menyatakan bahwa perceived usefulness merupakan determinan penting bagi perilaku user.

Menurut Lewis et al.(2003) variabel yang paling penting dalam menjelaskan interpretasi kognitif mengenai teknologi informasi adalah hal-hal yang berkaitan dengan individu. Meskipun penelitian-penelitian terdahulu telah menguji sejumlah faktor individual terhadap penerimaan teknologi, dua variabel penting yang secara konsisten ditemukan mempengaruhi penerimaan teknologi adalah self-efficacydan innovativeness. Menurut Roger sebagaimana dinyatakan oleh Lewis (2003) karakteristik seseorang akan membentuk keyakinan mengenai teknologi baru dengan menggabungkan informasi dari sejumlah chanel termasuk media masa dan hubungan interpersonal. Lee, Tae dan Chung, (2003) menemukan bahwa self-efficacy mempunyai pengaruh signifikan terhadap perceived usefulness dan mempunyai peran yang kritis dalam penerimaan teknologi oleh pemakai. Sementara peneliti yang lainnya Kulviwat, et al,. (2005) menemukan bahwa self-efficacy mempengaruhi secara tidak langsung pada attitude melalui perceived usefulness.

Dalam disiplin teknologi informasi, para peneliti menemukan bahwa self efficacy mempengaruhi harapan yang kemudian berdampak pada persepsi seseorang mengenai manfaat (perceived usefullness). Atas dasar ini, maka dikembangkan hipotesis sebagai berikut: H2: Self-efficacy berpengaruh terhadap persepsi kemanfaatan dalam penggunaan teknologi informasi.

\section{c. Pengaruh dukungan organisasi (pemerintah) terhadap persepsi atas kemanfaatan}


Ada banyak studi dalam literatur sistem informasi yang sudah memperluas model TAM dengan menambahkan variabel eksternal mengenai fitur teknologi, situasi riset dan tujuan (Kim, et al., 2007). Ketiadaan dukungan organisasi dianggap sebagai penghalang utama keberhasilan pemanfaatan suatu sistem (Igbaria, 1990, mengutip dari Chatzoglou, et al., 2010; Igbaria, et al., 1997; Kim, et al., 2007).

Faktor-faktor dukungan organisasi telah ditambahkan kepada model untuk mencerminkan cukup dukungan dan promosi yang ditawarkan oleh organisasi dalam penerimaan suatu teknologi (Kim, et al., 2007). Lin \& Wu (2004), menemukan bahwa dukungan manajemen secara langsung mempengaruhi persepsi atas kemanfaatan sistem. H3: Dukungan organisasi (pemerintah) berpengaruh positif dan signifikan terhadap persepsi atas kemanfaatan dalam mengadopsi teknologi informasi.

\section{d. Pengaruh kualitas sistem terhadap persepsi atas kemanfaatan}

Menurut Loudon and Loudon(2004), sistem informasi adalah sekumpulan komponen yang saling berhubungan, mengumpulkan, memproses, menyimpan, dan mendistribusikan informasi untuk menunjang pengambilan keputusan dan pengawasan dalam suatu organisasi. Berorientasi sistem tampilan menunjukkan bahwa hambatan untuk penerimaan konsumen yang berbasis teknologi. Tingkat kualitas yang tinggi sistem dapat memberikan pengguna kenyamanan lebih, privasi, dan lebih cepat tanggaplederer at al (2000). Liao dan Cheung (2001) menemukan bahwa kemampuan sistem tersebut memiliki dampak positif pada persepsi kemudahan penggunaan dan kegunaan dari situs.

Jogiyanto (2007) menjelaskan bahwa Kualitas sistem digunakan untuk mengukur kualitas sistem teknologi itu sendiri. Di lihat dari pengaruhnya terhadapa persepsi atas kemanfaatan Ahn et al. (2007) menyimpulkan bahwa kualitas sistem berpengaruh positif terhadap persepsi atas kemanfaatan dalam menggunakan teknologi. H4: Kualiatas sistem berpengaruh positif dan signifikan terhadap persepsi atas kemanfaatan.

\section{e. Pengaruh Persepsi atas Kemanfaatan terhadap Minat Menggunakan Teknologi Informasi}

Menurut Davis (1989), persepsi kemanfaatan (perceived usefulness) didefinisikan sebagaisejauh mana seseorang percaya bahwa dalam menggunakan teknologi tertentu akan dapat meningkatkan kinerjanya. Jadi, orang-orang cenderung akan menggunakan atau tidak menggunakan suatu aplikasi sejauh bahwa mereka percaya hal itu akan meningkatkan kinerja dari pekerjaan mereka. Menurut Philips et al (1994) dalam (Teo, Lee, dan Chai, 2007), persepsi kegunaan (perceived usefulness) mencerminkan probabilitas subjektif dari calon pengguna yang menerapkan teknologi baru, apakah akan bermanfaat bagi diri sendiri atau organisasinya. 
Ahn et al. (2007) menemukan bahwa persepsi atas kemanfaatan berpengaruh positif dan signifikan terhadap intensi menggunakan teknologi Informasi. Dalam penelitian lain Rahmawaty (2010) menunjukkan bukti empiris bahwa persepsi kebermanfaatan berpengaruh secara signifikan terhadap sikap user dalam menggunakan teknologi informasi. Penelitian Kusumo (2010) juga menunjukkan bahwa persepsi kebermanfaatan berpengaruh positif terhadap keinginan menggunakan teknologi informasi, dengan mengkonfirmasi penelitian Taylor dan Todd (1995) serta Sun (2003)..Berdasarkan hasil penelitian tersebut, peneliti tertarik untuk menguji kembali dengan rumusan hipotesis sebagai berikut: H5: Persepsi atas kemanfaatan berpengaruh positif dan signifikan terhadap minat menggunakan teknologi informasi.

\subsection{Kerangka Konseptual}

Berdasarkan tinjauan teori, kerangka konseptual penelitian seperti yang disajikan dalam gambar di bawah ini:

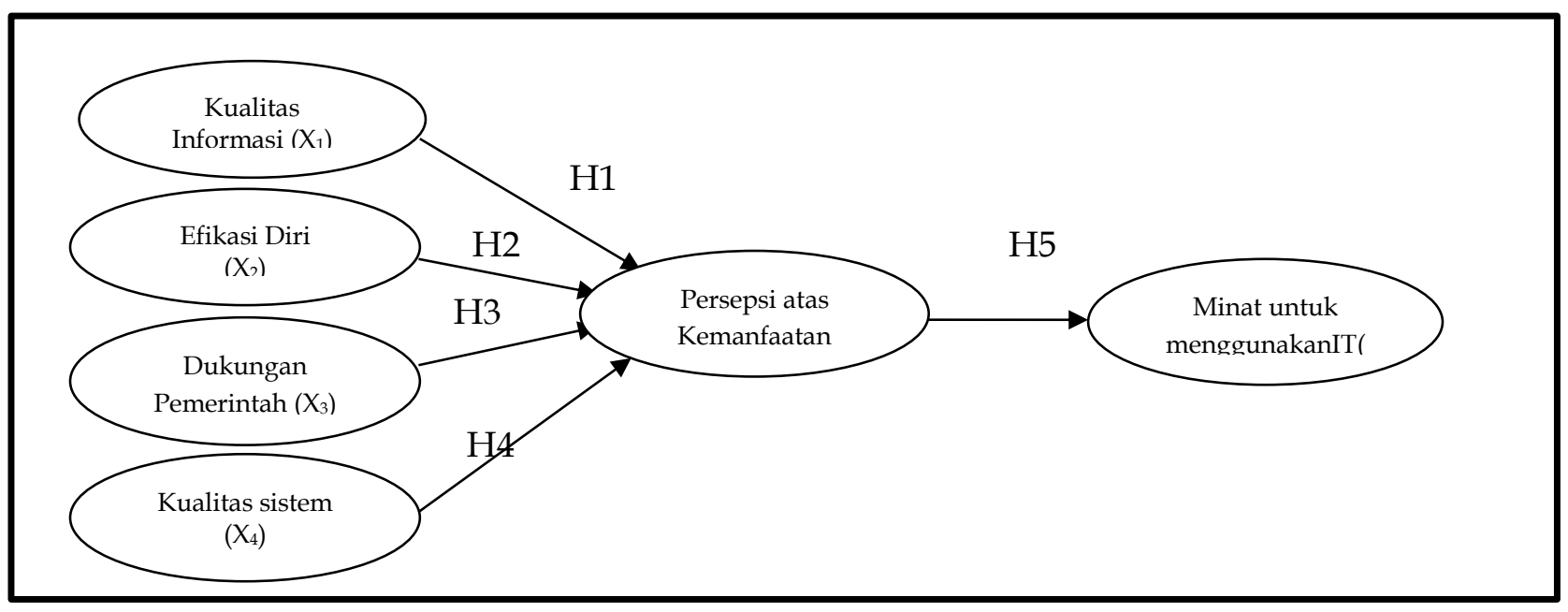

Gambar 1. Kerangka Pemikiran

\section{METODE PENELITIAN}

Desain penelitian menggunakan jenis penelitian yang dilakukan bersifat explanatory dengan teknik survey yang memiliki horizon waktu cross section melalui penyebaran kuisioner. Populasi yang akan digunakan dalam penelitian ini adalah usaha kecil menengah berbasis industri kreatif yang ada di Sumatra Barat.Usaha Kecil dan Menengah disingkat UKM adalah sebuah istilah yang mengacu ke jenis usaha kecil yang memiliki kekayaan bersih paling banyak Rp 200.000.000 tidak termasuk tanah dan bangunan tempat usaha dan usaha yang berdiri sendiri. Menurut Keputusan Presiden RI no. 99 tahun 1998 pengertian Usaha Kecil adalah kegiatan ekonomi rakyat yang berskala kecil dengan bidang usaha yang secara mayoritas merupakan kegiatan usaha kecil dan perlu dilindungi untuk mencegah dari persaingan usaha yang tidak sehat. 
Teknik pengambilan sampel di dalam penelitian ini dilakukan dengan teknik Purposive Sampling. Dimana teknik Purposive Sampling merupakan teknik pengambilan sampel yang dipilih oleh peneliti berdasarkan kriteria yang sudah ditentukan. Pelaksanaan Purposive Sampling dalam penelitian ini diberikan kepada usaha kecil menengah berbasis industri kreatif yang ada di Sumatra Barat. Kriteria yang ditetapkan sebahagiannya merujuk kepada kriteria usaha kecil menurut UU No. 9 tahun 1995 dan ditambah dengan kriteria dari industri kreatif dan wilayah penelitian. Kriteria yang ditetapkan adalah sebagai berikut :

a. Usaha Kecil Menengah atau mikro.

b. Bergerak dibidang industri kreatif.

c. Lokasi usaha berada di wilayah Sumatra Barat.

d. Memiliki kekayaan bersih paling banyak Rp. 200.000.000,- (Dua Ratus Juta Rupiah) tidak termasuk tanah dan bangunan tempat usaha.

e. Memiliki hasil penjualan tahunan paling banyak Rp. 1.000.000.000,- (Satu Miliar Rupiah).

f. Milik Warga Negara Indonesia.

g. Berdiri sendiri, bukan merupakan anak perusahaan atau cabang perusahaan yang tidak dimiliki, dikuasai, atau berafiliasi baik langsung maupun tidak langsung dengan Usaha Menengah atau Usaha Besar.

h. Berbentuk usaha orang perorangan, badan usaha yang tidak berbadan hukum, atau badan usaha yang berbadan hukum, termasuk koperasi.

Jenis data yang digunakan untuk mendapatkan data-data keterangan yang dibutuhkan yaitu dengan menggunakan data primer. Pengumpulan data pada penelitian ini dilakukan dengan menggunakan kuesioner yang berisi butir-butir pengukur konstruk atau variabel dalam bentuk daftar pertanyaan dan pernyataan yang digunakan dalam model penelitian.

\subsection{Variabel Penelitian dan Definisi Operasional}

Tabel 1

Variabel Penelitian dan Defini Operasional

\begin{tabular}{|c|c|c|c|c|c|c|}
\hline No. & Variabel & Defini Variabel & Indikator & $\begin{array}{l}\text { Jumlah } \\
\text { Item }\end{array}$ & Skala & Sumber \\
\hline 1 & $\begin{array}{l}\text { Kualitas } \\
\text { informasi }\end{array}$ & $\begin{array}{l}\text { suatu fungsi } \\
\text { yang } \\
\text { menyangkut } \\
\text { nilai dari } \\
\text { keluaran } \\
\text { informasi yang } \\
\text { dihasilkan oleh } \\
\text { sistem }\end{array}$ & 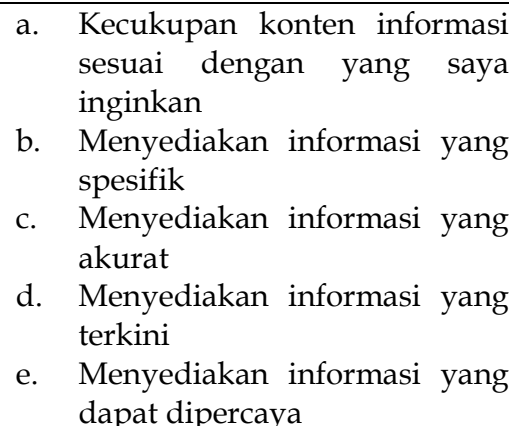 & 5 (lima) & $\begin{array}{l}\text { Likert } \\
1-5\end{array}$ & $\begin{array}{l}\text { Tony Ahn, Seewon Ry and } \\
\text { Ingoo Han. 2007. The } \\
\text { impact of web quality and } \\
\text { playfulness on user } \\
\text { acceptance of online } \\
\text { retailing }\end{array}$ \\
\hline
\end{tabular}




\begin{tabular}{|c|c|c|c|c|c|c|c|}
\hline 2 & Self Efficacy & $\begin{array}{l}\text { penilaian } \\
\text { seseorang } \\
\text { terhadap } \\
\text { kemampuanny } \\
\text { a sendiri untuk } \\
\text { mengorganisas } \\
\text { i dan } \\
\text { memutuskan } \\
\text { tindakan yang } \\
\text { diperlukan dari } \\
\text { suatu keadaan } \\
\text { untuk } \\
\text { rnencapai } \\
\text { kinerja } \\
\text { tertentu. }\end{array}$ & $\begin{array}{l}\text { a. } \\
\text { b. } \\
\text { c. } \\
\text { d. } \\
\text { e. } \\
\text { f. } \\
\text { g. } \\
\text { h. } \\
\text { i. } \\
\text { j. }\end{array}$ & $\begin{array}{l}\text { Masalah sulit selalu bisa diatasi } \\
\text { jika sering dicoba } \\
\text { Menemukan cara dan jalan } \\
\text { untuk mencapai hal yang } \\
\text { diinginkan } \\
\text { Keyakinan menangani masalah } \\
\text { lebih efisien pada kejadian } \\
\text { yang tidak terduga } \\
\text { Tahu cara menangani situasi } \\
\text { yang tak terduga } \\
\text { Kemudahan untuk tetap pada } \\
\text { tujuan dan menyelesaikannya } \\
\text { Fokus pada upaya yang } \\
\text { diperlukan } \\
\text { memecahkan masalah } \\
\text { Dapat mengandalkan } \\
\text { kemampuan untuk mengatasi } \\
\text { masalah } \\
\text { Bisa menemukan solusi } \\
\text { masalah } \\
\text { Bisa memikirkan solusi dari } \\
\text { masalah } \\
\text { Apapun masalah yang datang } \\
\text { bisa menghadapinya }\end{array}$ & $\begin{array}{c}10 \\
\text { (sepuluh) }\end{array}$ & $\begin{array}{l}\text { Likert } \\
1-5\end{array}$ & 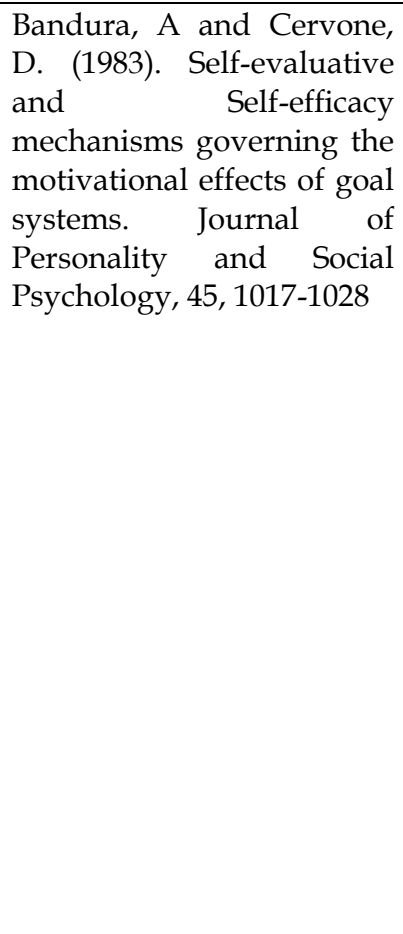 \\
\hline 3 & $\begin{array}{l}\text { Dukungan } \\
\text { pemerintah }\end{array}$ & $\begin{array}{l}\text { seperangkat } \\
\text { aturan yang } \\
\text { dimaksudkan } \\
\text { untuk } \\
\text { memberikan } \\
\text { perlindungan } \\
\text { dan manfaat } \\
\text { untuk } \\
\text { masyarakat } \\
\text { pada } \\
\text { umumnya atau } \\
\text { pada } \\
\text { sekelompok } \\
\text { masyarakat }\end{array}$ & $\begin{array}{l}\text { a. } \\
\text { b. } \\
\text { c. } \\
\text { d. } \\
\text { e. } \\
\text { f. } \\
\text { g. } \\
\text { h. }\end{array}$ & $\begin{array}{l}\text { Perhatian sedikit pada ukm } \\
\text { Peduli dengan kesejahteraan } \\
\text { ukm } \\
\text { Mempertimbangkan tujuan } \\
\text { dan nilai bisnis saya } \\
\text { Peduli dengan usul/pendapat } \\
\text { Ketika menjalankan usaha } \\
\text { dengan baik, pemerintah tidak } \\
\text { dapat melihatnya } \\
\text { Bangga dengan kesuksesan } \\
\text { ukm } \\
\text { Bersedia untuk membantu } \\
\text { ukm } \\
\text { Membantu ketika ada masalah } \\
\text { ukm }\end{array}$ & 8 (delapan) & $\begin{array}{l}\text { Likert } \\
1-5\end{array}$ & $\begin{array}{l}\text { Dixie villanueva and nikola } \\
\text { djurkovic. } 2009 . \\
\text { Occupational stress and } \\
\text { intention to leave among } \\
\text { employees in small and } \\
\text { medium enterprises }\end{array}$ \\
\hline 4 & Kualitas sistem & $\begin{array}{l}\text { suatu ukuran } \\
\text { pengolahan } \\
\text { sistem } \\
\text { informasi itu } \\
\text { sendiri }\end{array}$ & $\begin{array}{l}\text { a. } \\
\text { b. } \\
\text { c. } \\
\text { d. }\end{array}$ & $\begin{array}{l}\text { Penampilan Teknologi } \\
\text { Informasi membantu dalam } \\
\text { usaha } \\
\text { Kecepatan internet } \\
\text { memudahkan menjalankan } \\
\text { usaha } \\
\text { merasa aman menggunakan } \\
\text { Teknologi Informasi } \\
\text { bisa menggunakan Teknologi } \\
\text { Informasi ketika ingin } \\
\text { menggunakannya }\end{array}$ & 4 (empat) & $\begin{array}{l}\text { Likert } \\
1-5\end{array}$ & $\begin{array}{l}\text { Tony Ahn, Seewon Ry and } \\
\text { Ingoo Han. 2007. The } \\
\text { impact of web quality and } \\
\text { playfulness on user } \\
\text { acceptance of online } \\
\text { retailing }\end{array}$ \\
\hline 5 & $\begin{array}{l}\text { Persepsi atas } \\
\text { kemanfaatan }\end{array}$ & $\begin{array}{l}\text { Persepsi } \\
\text { kebermanfaata } \\
\mathrm{n} \text { merupakan } \\
\text { sejauh mana } \\
\text { seseorang } \\
\text { percaya bahwa } \\
\text { menggunakan } \\
\text { suatu teknologi } \\
\text { akan } \\
\text { meningkatkan } \\
\text { kinerjanya. }\end{array}$ & $\begin{array}{l}\text { a. } \\
\text { b. } \\
\text { c. } \\
\text { d. } \\
\text { e. } \\
\text { f. }\end{array}$ & $\begin{array}{l}\text { menghemat waktu dalam } \\
\text { meneyelesaikan pekerjaan } \\
\text { proses kegiatan bisnis akan } \\
\text { lebih baik } \\
\text { produktivitas bisnis akan lebih } \\
\text { meningkat } \\
\text { bisnis akan lebih efektif } \\
\text { bisnis akan lebih mudah } \\
\text { dikerjakan } \\
\text { manfaat teknologi informasi } \\
\text { ditemukan dalam bisnis }\end{array}$ & 6 (enam) & $\begin{array}{l}\text { Likert } \\
1-5\end{array}$ & $\begin{array}{l}\text { Davis, F. D (1989) Perceived } \\
\text { Usefulness, Perceived of } \\
\text { Ease to Use and User } \\
\text { Acceptance of Information } \\
\text { Technology. MIS Quartely, } \\
\text { Vol.13, No.3, pp } 319 \text { - } 340\end{array}$ \\
\hline
\end{tabular}




\begin{tabular}{|c|c|c|c|c|c|c|c|}
\hline 6 & $\begin{array}{l}\text { Intensi untuk } \\
\text { menggunakan }\end{array}$ & $\begin{array}{l}\text { Intensi untuk } \\
\text { mengadopsi } \\
\text { adalah } \\
\text { kecenderungan } \\
\text { perilaku } \\
\text { untuk tetap } \\
\text { menggunakan } \\
\text { suatu } \\
\text { teknologi. }\end{array}$ & $\begin{array}{l}\text { a. } \\
\text { b. } \\
\text { c. }\end{array}$ & $\begin{array}{l}\text { Pada masa yang akan datang } \\
\text { berniat untuk meningkatkan } \\
\text { penggunaan } \\
\text { Pada masa yang akan datang } \\
\text { berniat untuk menggunakan } \\
\text { teknologi informasi } \\
\text { pada masa yang akan datang } \\
\text { membutuhkan teknologi } \\
\text { informasi }\end{array}$ & 3 (tiga) & $\begin{array}{l}\text { Likert } \\
1-5\end{array}$ & $\begin{array}{l}\text { Adapted from Greer and } \\
\text { Murtaza (2003) }\end{array}$ \\
\hline
\end{tabular}

\subsection{Pengujian data}

Penelitian ini akan menggunakan metode analisis Partial Least Square (PLS). Pendekatan PLS adalah distribution free (tidak mengasumsikan data berdistribusi tertentu, dapat berupa nominal, kategori, ordinal, interval dan rasio. Selain dapat digunakan untuk mengkonfirmasi teori, PLS juga dapat digunakan untuk menjelaskan ada atau tidaknya hubungan antar variable laten (Ghozali, 2014). Dalam PLS akan dilihat Measurement (Outer) Model berupa Convergent Validity, Discriminant Validity dan Composite Reliability serta akan dilihat uji hipotesis dengan ketentuka karena PLS tidak mengasumsikan normalitas dan distribusi data, maka PLS menggunakan nonparametric test untuk menentukan tingkat signifikansi dari path coefficient, dimana nilai $\mathrm{t}$ (t-statistik) yang dihasilkan dengan menjalankan algorithm Boostrapping pada Smart PLS digunakan untuk menentukan diterima atau tidaknya hipotesis yang diajukan. Hipotesis akan diterima apabila nilai t-statistik melebihi nilai t tabel untuk derjat sinifikansi 0,05 sebesar 1.96 (Ghozali, 2014).

\section{HASIL PENELITIAN DAN PEMBAHASAN}

\subsection{Karakteristik Responden}

Berdasarkan hasil pengolahan data dari 200 pemilik atau pengelola UKM berbasis industri kreatif yang ada di Provinsi Sumatra Barat pada umumnya pemilik usaha atau pengelola usaha industri kreatif di Sumatera Barat adalah laki-laki sebanyak133 orang (66,5\%) dari total responden, dan sisanya responden perempuan yaitu sebanyak 67 orang (33,5\%). Kemudian pada umumnya memiliki pendidikan terakhir Tamat SLTA/sederajat adalah responden terbesar yaitu sebanyak 97 orang $(48,45 \%)$, dimana responden memiliki atau mengelola badan usaha secara perseorangan sebanyak 165 orang $(82,5 \%)$ dan responden adalah pemilik dan pengelola usaha sebanyak 95 orang $(47,5 \%)$, serta responden memiliki atau mengelola usaha industri kreatifnya $<5$ tahun sebanyak 104 orang (52\%) dimana tenaga kerja yang bekerja pada industri kreatif yang dimiliki atau dikelola pengusaha industri kreatif berkisar < 3 orang sebanyak 112 responden (56\%).

\subsection{Pengujian Data Model Pengukuran (Outer Model)}

\section{a. Uji Validitas}

Hasil pengujian dievaluasi berdasarkan convergent dan discriminant validity. Convergent validity dinilai berdasarkan korelasi (outer loading) antara skor item atau indikator (component 
score) dengan skor konstruk. Validitas konvergen dikatakan tinggi jika nilai loading atau korelasi skor indikator dengan skor konstruk di atas 0,7 (Chin dalam Ghozali, 2014. Jika skor loading antara 0,5 - 0,7, sebaiknya peneliti tidak menghapus indikator yang memiliki skor loading tersebut sepanjang AVE-nya besar dari 0,5 (Hartono dan Abdillah, 2009).

Tabel 2

AVE (Average Variance Extracted)Re-estimasi

\begin{tabular}{lc}
\hline & AVE \\
\hline dukungan pemerintah & 0,562 \\
\hline efikasi diri & 0,587 \\
\hline kualitas informasi & 0,607 \\
\hline kualitas sistem & 0,604 \\
\hline minat untuk menggunakan & 0,778 \\
\hline persepsi atas kemanfaatan & 0,677 \\
Sumber: Olahan Data Primer SMARTPLS $3(2015)$
\end{tabular}

Hasil pengolahan data re-estimasi di atas memperlihatkan nilai AVE semua variabel sudah memenuhi rule of thumb yang disyaratkan (AVE > 0,50). Namun dalam penelitian ini dipergunakan nilai outer loading $>0,60$ untuk mendapatkan AVE $>0,50$ dikarenakan pada saatouter loading $>0,50$ nilai AVE variabel ada yang tidak memenuhi rule of thumb yang disyaratkan (AVE > 0,50). Hal ini diperbolehkan seperti yang diungkapkan Hartono dan Abdillah (2009) yang mengatakan jika skor loading antara 0,5 - 0,7, sebaiknya peneliti tidak menghapus indikator yang memiliki skor loading tersebut sepanjang AVE-nya besar dari 0,50 .

Nilai cross loading dari setiap indikator berdasarkan hasil uji instrumen dapat dilihat pada tabel 3 berikut

Tabel 3

Cross Loading

\begin{tabular}{lcccccc}
\hline & $\begin{array}{c}\text { dukungan } \\
\text { pemerintah }\end{array}$ & $\begin{array}{l}\text { efikasi } \\
\text { diri }\end{array}$ & $\begin{array}{c}\text { kualitas } \\
\text { informasi }\end{array}$ & $\begin{array}{c}\text { kualitas } \\
\text { sistem }\end{array}$ & $\begin{array}{c}\text { minat untuk } \\
\text { menggunakan }\end{array}$ & $\begin{array}{c}\text { persepsi atas } \\
\text { kemanfaatan }\end{array}$ \\
\hline Pak1 & 0,024 & 0,122 & 0,301 & 0,491 & 0,437 & $\mathbf{0 , 7 6 9}$ \\
Pak2 & 0,077 & 0,132 & 0,264 & 0,513 & 0,561 & $\mathbf{0 , 8 3 8}$ \\
Pak3 & 0,115 & 0,091 & 0,285 & 0,496 & 0,512 & $\mathbf{0 , 9 0 1}$ \\
Pak4 & 0,173 & 0,080 & 0,246 & 0,457 & 0,524 & $\mathbf{0 , 8 8 3}$ \\
Pak5 & 0,239 & 0,038 & 0,296 & 0,389 & 0,442 & $\mathbf{0 , 8 0 5}$ \\
Pak6 & 0,300 & 0,200 & 0,279 & 0,418 & 0,370 & $\mathbf{0 , 7 2 6}$ \\
\hline
\end{tabular}




\begin{tabular}{lllllll}
\hline dp2 & $\mathbf{0 , 7 3 5}$ & 0,104 & 0,295 & 0,316 & 0,135 & 0,193 \\
dp3 & $\mathbf{0 , 7 7 2}$ & 0,149 & 0,297 & 0,221 & 0,076 & 0,106 \\
dp4 & $\mathbf{0 , 7 7 0}$ & $-0,015$ & 0,246 & 0,160 & 0,016 & 0,097 \\
dp6 & $\mathbf{0 , 6 8 7}$ & 0,019 & 0,191 & 0,102 & 0,076 & 0,134 \\
dp7 & $\mathbf{0 , 7 5 6}$ & 0,102 & 0,278 & 0,194 & 0,117 & 0,108 \\
dp8 & $\mathbf{0 , 7 7 4}$ & 0,047 & 0,274 & 0,227 & 0,085 & 0,110 \\
\hline mum1 & 0,103 & 0,158 & 0,267 & 0,425 & $\mathbf{0 , 8 7 2}$ & 0,484 \\
mum2 & 0,062 & 0,206 & 0,299 & 0,502 & $\mathbf{0 , 8 9 9}$ & 0,578 \\
mum3 & 0,168 & 0,197 & 0,316 & 0,483 & $\mathbf{0 , 8 7 5}$ & 0,469 \\
\hline pki1 & 0,170 & 0,213 & $\mathbf{0 , 7 4 6}$ & 0,486 & 0,265 & 0,263 \\
pki2 & 0,309 & 0,127 & $\mathbf{0 , 8 0 7}$ & 0,528 & 0,377 & 0,291 \\
pki3 & 0,303 & 0,282 & $\mathbf{0 , 8 3 0}$ & 0,411 & 0,270 & 0,240 \\
pki4 & 0,257 & 0,229 & $\mathbf{0 , 7 2 4}$ & 0,447 & 0,227 & 0,188 \\
pki5 & 0,333 & 0,224 & $\mathbf{0 , 7 8 3}$ & 0,435 & 0,156 & 0,301 \\
\hline pksp1 & 0,158 & 0,189 & 0,466 & $\mathbf{0 , 7 3 5}$ & 0,455 & 0,382 \\
pksp2 & 0,201 & 0,238 & 0,472 & $\mathbf{0 , 8 8 3}$ & 0,551 & 0,606 \\
pksp3 & 0,311 & 0,124 & 0,480 & $\mathbf{0 , 7 0 2}$ & 0,246 & 0,306 \\
pksp4 & 0,271 & 0,122 & 0,466 & $\mathbf{0 , 7 7 7}$ & 0,327 & 0,366 \\
\hline se1 & $-0,009$ & $\mathbf{0 , 7 3 0}$ & 0,219 & 0,174 & 0,187 & 0,085 \\
se3 & 0,109 & $\mathbf{0 , 7 5 3}$ & 0,285 & 0,237 & 0,151 & 0,087 \\
se6 & 0,105 & $\mathbf{0 , 8 1 4}$ & 0,149 & 0,133 & 0,158 & 0,125 \\
\hline sur & 0,37 & \\
\hline
\end{tabular}

Sumber: Olahan Data Primer SMARTPLS 3 (2015)

Pada tabel 3 di atas terlihat, bahwa nilai cross loading semua indikator (dicetak tebal) terhadap variabelnya lebih besar dari nilai loading indikator tersebut ke variabel lain. Hasil ini menunjukkan bahwa seluruh variabel laten memiliki discriminant validity yang baik.

\section{b. Uji Reliabilitas}

Reliabilitas instrumen pada penelitian ini ditentukan dari nilai composite reliability untuk setiap blok indikator pada konstruk reflektif. Rule of thumb nilai composite reliability harus lebih besar dari 0,7 meskipun nilai 0,6 masih dapat diterima (Hair et al., 2011). Composite reliability dari setiap variabel yang diteliti dapat dilihat pada tabel 4 berikut. 
Tabel 4

Uji Reliabilitas

\begin{tabular}{lc}
\hline \multicolumn{1}{c}{ Variabel } & Composite Reliability \\
\hline dukungan pemerintah & 0,885 \\
\hline efikasi diri & 0,810 \\
\hline kualitas informasi & 0,885 \\
\hline kualitas sistem & 0,858 \\
\hline minat untuk menggunakan & 0,913 \\
\hline persepsi atas kemanfaatan & 0,926
\end{tabular}

Sumber: Olahan Data Primer SMARTPLS 3 (2015)

Tabel $4 \mathrm{di}$ atas memperlihatkan nilai composite reliability dari setiap variabel yang diukur mempunyai nilai lebih besar dari 0,70, sehingga indikator yang digunakan dalam variabel penelitian tersebut dikatakan reliabel.

\subsection{Pengujian Model Struktural (Inner Model)}

Model struktural terdiri dari konstruk-konstruk laten yang tidak dapat diobservasi yang mempunyai hubungan teori. Pengujian ini termasuk mengestimasi koefisien jalur yang mengidentifikasi kekuatan hubungan variabel dependen dengan independen. Pengujian model struktural menghasilkan nilai signifikansi hubungan jalur antar variabel laten dengan menggunakan fungsi bootstrapping. Model struktural PLS dievaluasi dengan menggunakan R-Square untuk konstruk dependen, nilai koefisien path atau t-values tiap path untuk uji signifikansi antar konstruk dalam model struktural (Hartono dan Abdillah, 2009).

Nilai koefisien path atau inner model menunjukkan tingkat signifikansi dalam pengujian hipotesis. Skor koefisien path atau inner model yang ditunjukkan oleh nilai T-statistic, harus di atas 1,96 untuk hipotesis dua ekor (two-tailed) dan di atas 1,64 untuk hipotesis satu ekor (one-tailed) untuk pengujian hipotesis pada alpha 5 persen (Hair et al., 2011). Pengujian model struktural penelitian ini dapat dilihat pada tabel 5 berikut. 
Tabel 5

Total Effects(Mean, STDEV, T-Values)

\begin{tabular}{|c|c|c|c|c|c|}
\hline & $\begin{array}{c}\text { Original } \\
\text { Sample (O) }\end{array}$ & $\begin{array}{c}\text { Sample } \\
\text { Mean (M) }\end{array}$ & $\begin{array}{l}\text { Standard } \\
\text { Error } \\
\text { (STERR) }\end{array}$ & $\begin{array}{c}\text { T Statistics } \\
(|\mathrm{O} / \mathrm{STERR}|)\end{array}$ & P Values \\
\hline $\begin{array}{l}\text { dukungan pemerintah -> } \\
\text { persepsi atas kemanfaatan }\end{array}$ & 0,020 & 0,044 & 0,065 & 0,303 & 0,762 \\
\hline $\begin{array}{l}\text { efikasi diri -> persepsi atas } \\
\text { kemanfaatan }\end{array}$ & 0,005 & 0,030 & 0,085 & 0,056 & 0,955 \\
\hline $\begin{array}{l}\text { kualitas informasi -> } \\
\text { persepsi atas kemanfaatan }\end{array}$ & $-0,004$ & $-0,011$ & 0,092 & 0,038 & 0,970 \\
\hline $\begin{array}{l}\text { kualitas sistem -> persepsi } \\
\text { atas kemanfaatan }\end{array}$ & 0,559 & 0,565 & 0,071 & 7,920 & 0,000 \\
\hline $\begin{array}{l}\text { persepsi atas kemanfaatan } \\
\text {-> minat untuk } \\
\text { menggunakan }\end{array}$ & 0,583 & 0,589 & 0,056 & 10,487 & 0,000 \\
\hline
\end{tabular}

Tabel 5 di atas menunjukkan uji signifikansi yang menunjukkan pengaruh antar variabel pada tingkat signikansi two tail $($ T-table $=1,96)$. Tabel tersebut memperlihatkan bahwa variabel dukungan pemerintah berpengaruh positif terhadap persepsi atas kemanfaatan $(0,020)$ dan tidak signifikan pada $a=0,05$ karena nilai statistik $0,303,<1,96$. variabel efikasi diri berpengaruh positif terhadap persepsi atas kemanfaatan $(0,005)$ dan tidak signifikan pada $\alpha=0,05$ karena nilai statistik $0,056<1,96$. variabel kualitas informasi berpengaruh negatif terhadap persepsi atas kemanfaatan ($0,004)$ dan tidak signifikan pada $a=0,05$ karena nilai statistik $0,038<1,96$. Variabel kualitas sistem berpengaruh positif terhadap persepsi atas kemanfaatan $(0,559)$ dansignifikan pada $\alpha=0,05$ karena nilai statistik 7,920 >1,96. Variabel persepsi atas kemanfaatan berpengaruh positif terhadap minat untuk menggunakan $(0,583)$ dansignifikan pada $\alpha=0,05$ karena nilai statistik $10,487>1,96$. Hasil pengujian model struktural seperti gambar dibawah ini. 


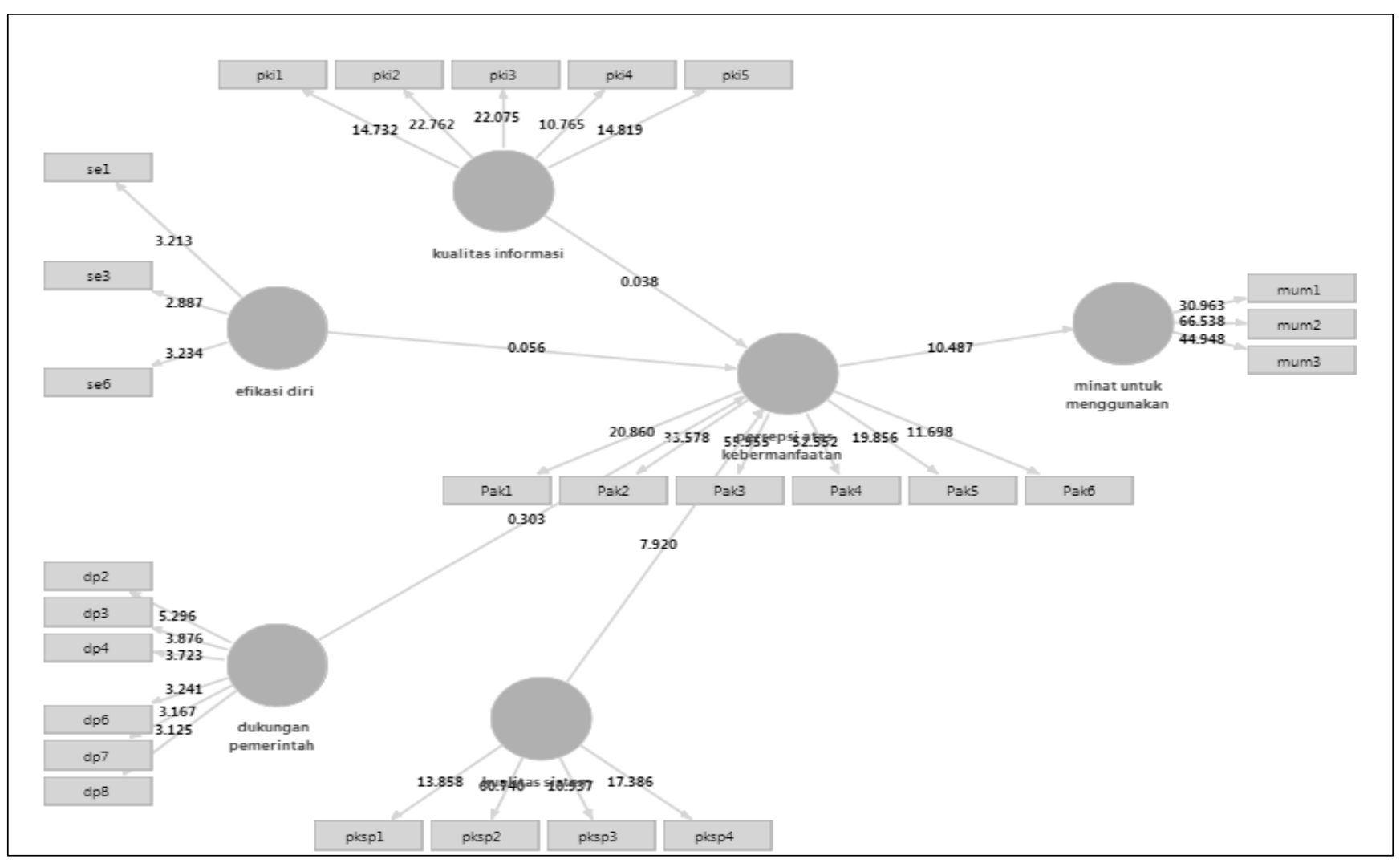

Gambar 2. Kerangka Pemikiran Bootstrapping

Untuk menilai signifikansi jalur antar variabel berdasarkan gambar 1 model struktural di atas dapat dilihat dari output PLS pada nilai t-statistic antar variabel yang ada di tabel total effects(tabel 4.27 di atas). Sehingga, hasil kesimpulan pengujian setiap hipotesis secara keseluruhan dilihat pada tabel 6 berikut.

\section{Tabel 6}

\section{Kesimpulan Pengujian Hipotesis}

\begin{tabular}{cll}
\hline Hipotesis & \multicolumn{1}{c}{ Pernyataan Hipotesis } & \multicolumn{1}{c}{ Hasil } \\
\hline H1 & variabel kualitas informasi berpengaruh negatif dan tidak & Negatif dan tidak \\
& signifikan terhadap persepsi atas kemanfaatan & signifikan \\
\hline H2 & variabel efikasi diri berpengaruh positif dan tidak & Positif dan tidak \\
& signifikan terhadap persepsi atas kemanfaatan & signifikan \\
\hline H3 & dukungan pemerintah berpengaruh positif dan tidak & Positif dan tidak \\
& signifikan terhadap persepsi atas kemanfaatan & signifikan \\
\hline H4 & Variabel kualitas sistem berpengaruh positiF & Positif* \\
& dansignifikan terhadap persepsi atas kemanfaatan & \\
\hline H5 & Variabel persepsi atas kemanfaatan berpengaruh positif & Positif* \\
& dansignifikan terhadap minat untuk menggunakan &
\end{tabular}

Catatan: Pengujian dilakukan pada tingkat signifikansi two-tail 
*) Signifikan pada $p<0.05$

Sumber: Olahan Data Primer SMARTPLS 3 (2015)

\subsection{Pembahasan dan Hasil Penelitian}

Hasil dari tabel 6 di atas menunjukkan uji signifikansi yang menunjukkan pengaruh antar variabel pada tingkat signikansi two tail (T-table $=1,96)$.

\section{a. Pengaruh Kualitas Informasi Terhadap Persepsi Atas Kemanfaatan}

Variabel kualitas informasi berpengaruh negatif terhadap persepsi atas kemanfaatan $(-0,004)$ dan tidak signifikan pada a=0,05 karena nilai statistik 0,038 < 1,96. Berdasarkan hasil temuan ini, dapat diartikan bahwa pemilik atau pengelola UKM di wilayah Provinsi Sumatra Barat merasa bahwa kecukupan informasi yang mereka peroleh belum sesuai dengan apa yang mereka inginkan, kemudian juga ketersediaan iinformasi yang spesifik, akurat, terkini dan dapat dipercaya juga belum mereka peroleh sebagaimana mestinya sebagai kemanfaatan dalam menggunakan teknologi informasi sehingga pemilik atau pengelola UKM beranggapan bahwa kualitas informasi yang tidak relevan akan dapat menurunkan persepsi atas kemanfaatan dalam penggunaan teknologi informasi.

Jogiyanto (2007) mengatakan kualitas informasi mengukur kualitas keluaran dari sistem informasi". Ong et al. (2009) berpendapat bahwa "Kualitas informasi dapat diartikan pengukuran kualitas konten dari sistem informasi". Negash et al. (2003) menjelaskan "Kualitas informasi adalah suatu fungsi yang menyangkut nilai dari keluaran informasi yang dihasilkan oleh sistem".

Berdasarkan beberapa pendapat para ahli, dapat disimpulkan bahwa kualitas informasi adalah suatu pengukuran yang berfokus pada keluaran yang diproduksi oleh sistem, serta nilai dari keluaran bagi pengguna. Maka hasil penelitian ini sejalan dengan pendapatt Jogiyanto (2005) menjelaskan bahwa kualitas informasi terdiri tiga hal yaitu Akurat, tepat pada waktunya, dan relevan. Hal ini mengindikasikan jika hal tersebut masih belum bisa terpenuhi maka kualitas informasi akan menurunkan persepsi atas kemanfaatan penggunaan teknologi informasi. Namun hasil penelitian ini tidak konsiten dengan hasil penelitian Ahn et al. (2006) menejelaskan bahwa kualitas informasi berpengaruh terhadap persepsi atas kemanfaatan

\section{b. Pengaruh Self Efficacy Terhadap Persepsi Kemanfaatan}

variabel efikasi diri berpengaruh positif terhadap persepsi atas kemanfaatan $(0,005)$ dan tidak signifikan pada a=0,05 karena nilai statistik 0,056 <1,96. Hal ini mengindikasikan meskipun pemilik atau pengelola UKM memiliki tingkat kepercayaan diri yang tinggi bahwa mereka bisa mendapatkan manfaat atas teknologi informasi pada usaha mereka 
namun kepercayaan diri tersebut belum mampu mengubah persepsi atas kemanfaatan penggunaaan teknologi informasi.

Hal ini mengindikasikan meski semakin tinggi penilaian pemilik atau pengelola UKM terhadap kemampuan dirinya dalam mengorganisasi dan memutuskan tindakan yang diperlukan untuk mencapai kinerja yang diinginkan, namun belum mampu mengubah persepsi mereka terhadap manfaat yang akan diterima dari pemanfaatan penggunaaan teknologi informasi. Lee, Tae dan Chung, (2003) menemukan bahwa self-efficacy mempunyai pengaruh signifikan terhadap perceived usefulness dan mempunyai peran yang kritis dalam penerimaan teknologi oleh pemakai. Sementara peneliti yang lainnya Kulviwat, et al. (2005) menemukan bahwa self-efficacy mempengaruhi secara tidak langsung pada attitude melalui perceived usefulness. Dalam disiplin teknologi informasi, para peneliti menemukan bahwa self efficacy mempengaruhi harapan yang kemudian berdampak pada persepsi seseorang mengenai manfaat (perceived usefullness). Hal ini mengindikasikan jika harapan yang diperoleh pemilik atau pengelola UKM di Sumatera Barat belum sesuai dengan apa yang mereka inginkan maka hal tersebut belum akan mempengaruhi atau berdampak pada persepsi seseorang mengenai manfaat dalam penggunaan teknologi informasi itu sendiri.

\section{c. Pengaruh Dukungan Pemerintah Terhadap Persepsi Kemanfaatan}

Dukungan pemerintah berpengaruh positif terhadap persepsi atas kemanfaatan $(0,020)$ dan tidak signifikan pada $a=0,05$ karena nilai statistik $0,303,<1,96$. Berdasarkan hasil temuan ini, dapat diartikan bahwa pemilik atau pengelola UKM di wilayah Provinsi Sumatra Barat merasa bahwa dukungan pemerintah terhadap persepsi atas kemanfaatan teknologi informasi masih belum sepenuhnya hal ini terlihat dari perhatian pemerintah yang masih sedikit, begitu juga dengan kepedulian pemerintah terhadap kesejahteraan UKM dan ketersediaan pemerintah itu sendiri dalam membantu dan mengatasi masalah yang dimiliki para pemilik atau pengelola UKM di Sumatera Barat, sehingga hal ini menyebabkan dukungan pemerintah belum mampu mempengaruhi perubahan atas persepsi kemanfaatan penggunaan teknologi informasi itu sendiri. Hal ini sejalan dengan pendapat (Igbaria, 1990, mengutip dari Chatzoglou, et al., 2010; Igbaria, et al., 1997; Kim, et al., 2007) yang mengatakan ketiadaan dukungan organisasi dianggap sebagai penghalang utama keberhasilan pemanfaatan suatu sistem.

Faktor-faktor dukungan organisasi telah ditambahkan kepada model untuk mencerminkan cukup dukungan dan promosi yang ditawarkan oleh organisasi dalam penerimaan suatu teknologi (Kim, et al., 2007). Selanjutnya Lin \& Wu (2004), menemukan bahwa dukungan manajemen secara langsung mempengaruhi persepsi atas kemanfaatan sistem. Hal ini 
mengindikasikan jika dukungan pemerintah masih rendah dan masih belum memneuhi harapan dari pemilik atau pengelola UKM maka tentu saja belum mampu mempengaruhi persepsi atas kemanfaatan teknologi informasi secara baik dan lebih efektif serta efisien.

\section{d. Pengaruh Kualitas Sistem Terhadap Persepsi Kemanfaatan}

Variabel kualitas sistem berpengaruh positif terhadap persepsi atas kemanfaatan $(0,559)$ dansignifikan pada $\alpha=0,05$ karena nilai statistik 7,920 > 1,96. Hal ini mengindikasikan bahwa pemilik atau pengelola UKM di wilayah Provinsi Sumatra Barat merasa bahwa penampilan teknologi informasi yang menarik akan membantu mereka dalam menjalankan usahanya, begitu juga dengan kecepatan internet dan rasa aman dalam menggunakan teknologi informasi dan kemudahan dalam menggunakan kapan dan dimana saja. Menurut Loudon and Loudon (2004:15), sistem informasi adalah sekumpulan komponen yang saling berhubungan, mengumpulkan, memproses, menyimpan, dan mendistribusikan informasi untuk menunjang pengambilan keputusan dan pengawasan dalam suatu organisasi.

berorientasi sistem tampilan menunjukkan bahwa hambatan untuk penerimaan konsumen yang berbasis teknologi. tingkat kualitas sistem yang tinggi dapat memberikan pengguna dengan kenyamanan lebih, privasi, dan lebih cepat tanggaplederer at al (2000). Liao dan Cheung (2001) menunjukkan bahwa kemampuan sistem tersebut memiliki dampak positif pada persepsi kemudahan penggunaan dan kegunaan dari situs. Hal ini sejalan dengan pendapat Jogiyanto (2007) menjelaskan bahwa "Kualitas sistem digunakan untuk mengukur kualitas sistem teknologi itu sendiri". Di lihat dari pengaruhnya terhadap persepsi atas kemanfaatan Tony Ahn et al (2006) menyimpulkan bahwa kualitas sistem berpengaruh positif terhadap persepsi atas kemanfaatan.

\section{e. Pengaruh Prsepsi Kemanfaatan Terhadap Minat Menggunakan Teknologi Informasi}

Variabel persepsi atas kemanfaatan berpengaruh positif terhadap minat untuk menggunakan $(0,583)$ dansignifikan pada $\alpha=0,05$ karena nilai statistik 10,487 >1,96. Hal ini mengindikasikan bahwa pemilik atau pengelola UKM di wilayah Provinsi Sumatra Barat merasa bahwa penggunaan teknologi informasi dapat menghemat waktu dalam meneyelesaikan pekerjaan, kemudian proses kegiatan bisnis akan lebih baik jika menggunakan teknologi informasi serta produktivitas bisnis akan lebih meningkat jika menggunakan teknologi informasi, bisnis akan lebih efektif dan mudah dikerjakan jika menggunakan teknologi informasi.

Menurut Davis (1989), persepsi kemanfaatan (perceived usefulness) didefinisikan sebagai sejauh mana seseorang percaya bahwa dalam menggunakan teknologi tertentu akan dapat meningkatkan kinerjanya. Jadi, orang-orang cenderung akan menggunakan atau tidak 
menggunakan suatu aplikasi sejauh bahwa mereka percaya hal itu akan meningkatkan kinerja dari pekerjaan mereka. Menurut Philips et al (1994), persepsi kegunaan (perceived usefulness) mencerminkan probabilitas subjektif dari calon pengguna yang menerapkan teknologi baru, apakah akan bermanfaat bagi diri sendiri atau organisasinya.

Tony Ahn et al (2006) menemukan bahwa persepsi atas kemanfaatan berpengaruh positif dan signifikan terhadap intensi menggunakan teknologi Informasi. Dalam penelitian lain Rahmawaty (2010) menunjukkan bukti empiris bahwa persepsi kebermanfaatan berpengaruh secara signifikan terhadap sikap user dalam menggunakan teknologi informasi. Penelitian Kusumo (2010) juga menunjukkan bahwa persepsi kebermanfaatan berpengaruh positif terhadap keinginan menggunakan teknologi informasi, dengan mengkonfirmasi penelitian Taylor dan Todd (1995) serta Sun (2003).

Penelitian lain yang dilakukan oleh Chau dan $\mathrm{Hu}$ (2001) terhadap 400 responden membuktikan bahwa persepsi kegunaan (perceived usefulness) memiliki pengaruh positif terhadap minat penerimaan teknologi telemedicine. Hasil yang sama juga didapat dari penelitian Rukiza et al (2010) tentang penggunaan e-government service di Tanzania.

\section{PENUTUP}

\subsection{Kesimpulan}

Berdasarkan hasil pengujian SEM (Structural Equational Modeling) dengan menggunakan Smart PLS maka dapat disimpulkan bahwa:

a. Variabel kualitas informasi berpengaruh negatif dan tidak signifikan terhadap persepsi atas kemanfaatan

b. Variabel efikasi diri berpengaruh positif dan tidak signifikan terhadap persepsi atas kemanfaatan

c. Dukungan pemerintah berpengaruh positif dan tidak signifikan terhadap persepsi atas kemanfaatan

d. Variabel kualitas sistem berpengaruh positif dansignifikan terhadap persepsi atas kemanfaatan

e. Variabel persepsi atas kemanfaatan berpengaruh positif dansignifikan terhadap minat untuk menggunakan

\subsection{Keterbatasan Penelitian}

Berdasarkan pengalaman yang peneliti alami selama melakukan proses penelitian, peneliti menyadari bahwa hasil penelitian ini tidak sempurna dan memiliki keterbatasan yang mungkin akan mempengaruhi hasil yang diharapkan. Oleh karena itu keterbatasan ini diharapkan lebih 
diperhatikan untuk peneliti yang akan datang. Keterbatasan yang dirasakan oleh peneliti adalah dalam proses pengambilan data, informasi yang diberikan responden melalui kuesioner terkadang tidak menunjukan pendapat responden yang sebenarnya, hal ini terjadi karena pemahaman yang berbeda dari pemilik dan pengelola UKM, juga faktor lain seperti ketepatan waktu dalam pengisian kuisioner dan faktor kejujuran dalam pengisian pendapat para responden dalam kuisionernya.

\subsection{Implikasi Penelitian}

Hasil penelitian bermanfaat dan sebagai bahan pertimbangkan dalam praktek manajemen khususnya yang berkaitan dengan faktor-faktor yang mempengaruhi intensi adopsi teknologi informasi pada industri kreatif di Sumatera Barat. Hasil penelitian juga bermanfaat bagi pengusaha yang berada di Provinsi Sumatra Barat untuk mempertimbangkan penerapan teknologi informasi dalam kegiatan bisnisnya.

\subsection{Saran}

a. Dalam penelitian selanjutnya, disarankan untuk mengambil sampel yang mewakili jumlah populasi, hal ini bertujuan untuk keakuratan data yang lebih baik dalam penelitiannya.

b. Melakukan penelitian yang berkelanjutan, hal ini agar dapat melihat dan meningkatkan operasional dari bisnis UKM berbasis industri kreatif di Provinsi Sumatra Barat.

c. Diharapkan adanya tambahan variable lain yang mungkin juga mempengaruhi banyak hal dalam penelitian ini misalnya dengan menambahkan variabel persepsi atas kemudahan (perceived of ease to use).

\section{DAFTAR PUSTAKA}

Ahn, Tony, Seewon, Ryu, dan Ingoo, Han (2007), “The Impact of Web Quality and Playfulness on User Acceptance of Online Retailing", Journal Technology Acceptance Model.

Ajzen, I., and M. Fishbein (1980), Understanding Attitudes and Predicting Social Behavior, Engletvood Cliffs, Prentice Hall, Inc, New Jersey.

Bandura, A. (1977). “Self-efficacy: Toward a Unifying Theory of Behavioral Change”, Psychological Review, Vol. 84, pp. 191-215.

Bandura. (1997). Self-Efficacy: The Exercise of Control, W.H. Freeman and Company, New York.

William, B. K., and Sawyer, S. C. (2007), Using Information Technology, Edisi Bahasa indonesia, Pengenalan Praktis Dunia Komputer dan Komunikasi.

Chatzoglu, T., Demetriades, P., \& Maditinos, D.E. (2005), Knoowledge Assets and Firm Performance : An Empirical Approach Examining the Causal Ambiguity Parado, Kavala, Greece: Business Administration Dept., TEI of Kowala. 
Chau, P. Y. K., \& Hu, P. J. H. (2001), "Information Technology Acceptance by Individual Professionals: A Model Comparison Approach", Decision Sciences, Vol. 32, pp. 699-719.

Chatzoglou, P. D., Vraimaki, E., Diamantidis, A., and Sarigianidis, L. (2010) “Computer Acceptance in Greek SMEs", Journal of Small Business and Enterprise Development, Vol. 17 No. 1, pp. 78101.

Chen, C.W. (2010), “Impact of Quality Antecedents on Taxpayer Satisfaction with Online Tax-Filling System An Emperical Study", Information \& Management, Vol. 47, No. 5-6, pp. 308-315.

Compeau, D.R and Higgins, C.A. (1995), “Application of Social Cognitive Theory to Training for Computer Skill”, Information Systems Research, Vol.6, No.2, pp. 118-143.

Davis, Fred D. (1989), "Perceived Usefulness, Perceived Ease of Use and User Acceptance of Information Technology", MIS Quarterly, Vol. 13, No. 3, pp. 319-339.

Djamhari, Choirul (2006), “Faktor-Faktor Yang Mempengaruhi Perkembangan Sentra UKM Menjadi Klaster Dinamis", Jurnal Pengkajian Koperasi dan UKM.

Ellitan, Lena (2002), “Technology Adoption, Technology Management and it's Impact on Operational Performance: A Case From Indonesia", Jurnal bisnis dan Akutansi, Vol.1, No.1, pp. $1-22$.

Goodhue, D.L. (1995), “Understanding User Evaluations of Information Systems”, Management Science, Vol. 41, No. 12,pp. 1827-1844.

Ghozali, Imam (2014), Structural Equation Modeling Metode Alternatif dengan Partial Least Squares (PLS), Badan Penerbit Universitas Diponegoro, Semarang.

Haag dan Keen (1996), Information Technology: Tomorrow's Advantage Today, Mcgraw-Hill College, Hammond.

Handayani, dkk. (2007), "Studi Korelasi Motivasi Pengguna dan Pemanfaatan Koleksi CD-ROM di UPT Pusat Perpustakaan UII Yogyakarta", Jurnal Berkala Ilmu Perpustakaan dan Informasi. Vol. 3, No. 7, Yogyakarta: Universitas Gadjah Mada.

Howkins, John (2001), The Creative Economy: How People Make Money from Ideas, Penguin. PJ., Hu, et al. (1999). “Examining the Technology Acceptance Model Using Physician Acceptance Oftelemedicine Technology", J. Manage. Info. Syst., Vol. 16, No. 2, pp. 91-112. Igbaria, M.N., Zinaelli, P.C., and Cavaye, L.M. (1997), "Personal Computing Acceptance Factors in Small Firms: A Structural Equation Model", MIS Quarterly, Vol. 21, No. 3, pp. 279-305.

Hall , James A. (2001). Sistem Informasi Akuntansi, Salemba Empat, Jakarta.

Jogianto, HM. (2005), Analisis \& Desain Sistem Informasi: Pendekatan Terstruktur, Teori, dan Aplikasi Bisnis, Edisi Ketiga, Andi, Yogyakarta.

Jogianto, HM. (2007), Model Kesuksesan Sistem Teknologi Informasi, Andi, Yogyakarta. 
Koufaris, Marios, dan Hampton-Sosa, W. (2004). "The Development of Initial Trust in an Online Company by New Costumer", Information and Management, Vol. 41, pp. 377-397.

Kulviwat, Songpol, et al. (2007), "Toward A Unified Theory of Consumer Acceptance Technology. Psychology \& Marketing", Vol. 24, No. 12, December 2007, pp. 1059-1084.

Lederer, A.L., Maupin, D.J., Sena, M.P. and Zhuang, Y. (2000), “The Technology Acceptance Model and The World Wide Web", Decision Support Systems, Vol. 29, No. 3, pp. 269-282.

Lee, Y.C., Li, M.L., Yen, T.M., dan Huang, T.H. (2010), “Analysis of Adopting an Integrated Decision

Making Trial and Evalution Laboratory on a Technology Acceptance Model”, Journal of Expert System with Aplication, Chung-Hua University, Taiwan.

Lewis, et al. (1998), Medical Surgical Nursing; Assesment and Management of Clinical Problem, Ed.

5, Philadelphia: Mosby.

Liao, Z., dan Cheung, M.T. (2001), "Internet-Based E-shopping and Consumer Attitudes: an Empirical study", Information and Management.

Maharsi, S. (2007), “Faktor-Faktor yang Mempengaruhi Minat Nasabah Menggunakan Internet Banking dengan Menggunakan Kerangka Technology Acceptance Model (TAM)", Jurnal Akuntansi Dan Keuangan, Vol. 9, No. 1, Mei 2007,pp. 18-28.

Moore, G. C., \& Benbasat, I. (1991), “Development of an Instrument to Measure the Perception of Adopting an Information Technology Innovation", Information Systems Research, Vol. 2, pp. 192-222.

Negash, S., Ryan, T., and Igbaria, M. (2003), "Quality and Effectiveness in Web Based Customer Support System”, Informasion \& Management, Vol. 40, No. 8, pp. 757-768.

Nelson, R. R., Tood, P. A., and Wixom, B.H. (2005), “'Antecedents of Information and System Quality: An Empirical Examination Within The Context of Data Warehousing"

Ong, C.S., Day, M.Y., and Hsu, W.L. (2009), “A Measurement of User Satisfactionwith Question Answering System”, Information and Management, Vol. 46, No. 7, pp. 397-403.

Pearson, J.M., Bahmanziari, T., Crisby, L., Conrad, E. (2003), “An Empirical Investigation into The Relationship Between Organizational Culture and Computer Efficacy as Moderated by Age and Gender", The Journal of Computer Information Systems, Vol. 43, No. 2, pp. 58 - 71.

Pervin, L. A., dan John, O.P. (1997), Personality: Theory and Research, John Wiley Sons,Inc, New York.

Rosid , Abdul (2004), “Manajemen Usaha Kecil, Menengah dan Koperasi”, Modul Manajemen UKM. Schillewaert, Niels, et al. (2000), “The Acceptance of Information Technology in the Sales Force", Business Research Center Working Paper.

Sekaran, Uma (2007), Research Methods For Business, Salemba Empat, Jakarta. 
Sekaran, Uma (2009), Research Methods For Business Metodologi Penelitian Untuk Bisinis, Buku I Ed. 4, Salemba Empat, Jakarta.

Singh, Inder dan Punia, Devendra Kumar (2010), "Employees Adoption of E-Procurement System: An Empirical Study", pp. 1-11.

Loudon, Kenneth C. (2004), Sistem Informasi Manajemen, Andi, Yogyakarta.

Sugiyono (2013), Metode Penelitian Pendidikan (Pendekatan Kuantitatif, Kualitatif, dan R\&D), Alfabeta, Bandung.

Teo, T., C.B. Lee, dan C.S Chai (2007), “Understanding Pre-Service Teachers' Computer Attitudes: Applying and Extending The Technology Acceptance Model", Journal Compilation, pp. 128143.

Wibowo (2008), Manajemen Kinerja, Rajagrafindo Persada, Jakarta.

William dan Sawyer (2007), Using Information Technologi, Andi, Yogyakarta. 